\title{
NECESSITY OF INTRODUCTION OF PENSION DISABILITY INSURANCE REFORM
}

\author{
PILJAN Tatjana ${ }^{1}$, LUKIC Marija ${ }^{2}$, PILJAN Ivan $^{3}$ \\ 1 Faculty of Business Economics and Entrepreneurship, Belgrade (SERBIA) \\ 2 Elementary school "Ivo Andrić", Belgrade (SERBIA) \\ 3 Faculty of Business Economics and Entrepreneurship, Belgrade (SERBIA) \\ E-mails :tanja.piljan@vspep.edu.rs,ukicmarija@gmail.com,ivan.piljan@vspep.edu.rs
}

\begin{abstract}
Life is a natural course, full of the uncertainty and temptation of every human being. In order to make our lives peaceful and have a peaceful future, we try to provide various ways to ensure that we make our lives safer.

The pension insurance system is very important for every country from a social, economic and financial point of view. Pensions are primarily a social category because they represent the income of people who are unable to earn a living due to age or illness and as such reflect the social function of the state.

In most of the transition countries, reforming processes in the field of pension insurance have been initiated or are under way in order to establish a sustainable functioning model. In Serbia, in the period from 2001 to 2016, attempts were made to reform the pension insurance system in order to solve the inherited unfavorable situation, but still without significant effects.

An integral part of the paper is the results of the research conducted with the aim of obtaining the attitude of Belgrade residents about the existing mandatory pension insurance and trust in the same, as well as the view on the need to take additional measures and activities in order to realize a comprehensive reform in the field of pension insurance. Starting from the established goal of the research, it can be concluded that the hypothesis was established that the inhabitants of Belgrade are not satisfied with the existing situation in the pension insurance system, that they consider the pension fund to be vacant and that as such it does not guarantee safe pensions. This indicates that additional measures and activities of the competent state authorities and institutions should be undertaken in the forthcoming period in order to fully implement the projected reform goals in the field of pension insurance.
\end{abstract}

Keywords: pension insurance system, social insurance, private pension insurance, reforms, research results, attitude of the inhabitants of Belgrade.

JEL: G22, G23

UDC: 364.35(497.11)

368.914(497.11)

COBISS.SR-ID 277963276 


\section{INTRODUCTION}

The pension system is very important for every country from a social, economic and financial point of view. Pensions are above all a social category because they represent the income of people who are unable, due to sickness or age, to earn a living and who need state care, and as such, pensions are part of the social security system, which is the most significant form of social insurance. Modern social insurance was created in Germany in the 80s of the 19 th century ([8], p. 72) when compulsory insurance of workers with major social risk factors was introduced, such as age, disability, illness and unemployment. In the period of liberal capitalism, workers with low wages, and there were many during that period, were unable to provide their own essential security. In order to reduce these risks, the state, through the system of contributions, provided the social security of workers. In this system, each of the insured (workers) regularly contributed to those users who were affected with one of the mentioned social risks ([1], p.7).

Pensions are also an economic category because long-term payments, when the population is actively earning, create large assets in the name of saving for old age. Finally, pensions are also a financial category. On the one hand, because pensions are part of public spending, and as such, are part of the public finances of a country. On the other hand, lately, with the reform of the pension system, private pension funds representing old age savings are one of the most important institutional investors in financial markets around the world and have a major impact on the financial systems of countries.

The pension systems of most countries in the world are based on a system of ongoing financing. This system is characterized by the fact that those who work, through contributions, finance the pensions of those people who have completed their working lives. Today this type of intergenerational solidarity is not sustainable in the long run. The main reasons for this tendency are of a demographic and financial nature. For the sustainability of such a pension system, demographic factors are not favorable due to the aging of the population and the increasing share of those over 65 in the total population, on one hand, and low fertility rates, or the number of newborns, on the other. As a result, employees are unable to fund pensions without an increase of their contributions.

The process of globalization, that is, the process of integration of the world economy, has a great impact on the reforms of the pension system, which also requires a reduction in investments in pension insurance. This paper aims to draw attention to the current situation as well as to propose potential solutions that would make the pension system stable and sustainable over the long run, as well as to stress the importance of life insurance in securing material security in old age. The paper will address the provision of material security in the old age through analysis of pension systems both in the world and in our country, with the reforms undertaken, and a special emphasis will be placed on pension system reforms in transition countries, the emergence of pension funds and their role in the financial market, as well as development of private pension insurance in Serbia. 


\section{REFORMS OF THE PENSION SYSTEM AND FINANCIAL SECURITY IN OLD AGE}

The reform of pension insurance is a big undertaking that affects the existential issues of the citizens of each country and therefore has a great social and political significance. Those who are working on the reform of the pension system in a country with a weak economy have a particularly difficult task, as it is also burdened by the consequences of war, economic sanctions and bombing. Reliance largely on the suggestions of the IMF and the World Bank by international organizations that have similar recipes for all non-developed countries can hardly have a good outcome ([2], p.121).

Developed European countries have no such problem, as their citizens, along with compulsory retirement, have some kind of voluntary insurance that guarantees them material security in their old age. In these countries, employers have a legal obligation to provide pensions to workers. Employers can pay into pension funds or direct life insurance that is paid as an annuity after retirement. In addition, all citizens can pay voluntary pension insurance, most often with life annuity insurance but rarely with pension funds. In order to maintain the desired level of income in the country's old age population, they undertake various measures, and regulations are adopted which, primarily through the tax policy, stimulate life insurance. The compulsory pension insurance business in some countries is being entrusted to national insurance companies because citizens have confidence in them, and they are also of great importance in supporting the development of the country's economy.

A successful reform involves the drafting of a set of legal, subordinate and administrative acts in order for pension insurance to be a complete system that will provide social justice. In the Law on Insurance applicable in Serbia, voluntary insurance has been given little space. Nevertheless, the least understandable segment of the pension insurance reform is that it is not envisaged to introduce compulsory pension insurance for employees that are concluded by employers. Funds from which the pensions of employees are paid operate on the basis of capitalization, and that is why they have an advantage over public funds. The introduction of voluntary insurance (3rd pillar) only through a pension fund in countries with low average wages and without tradition in that business is also debatable. It is necessary that regulations that would stimulate various types of voluntary pension insurance by a number of measures are a constituent part of the reform. A reform based on drastic reductions in compulsory insurance and voluntary insurance coverage does not have good prospects if a successful reform is one which in the long term protects both the individual interests of citizens and the broader national interests ([3], p.121).

In Serbia, an important way of organizing insurance, which is otherwise widely used in developed countries, is also neglected. It is well-known that non-profit mutual insurance companies largely provide insurance that has a social function (pension, health, insurance and old age care). These are companies that fail to charge the costs of their business (such as pension fund management companies) and through which the solidarity of those who want to protect themselves from poverty in old age is achieved in the best way. It would therefore be desirable to examine the experience of other countries in relation to the business of mutual insurance companies in order to achieve better solutions for categories of citizens such as, for example, farmers or members of independent professions. Obviously, the law favors the establishment of profit joint stock companies as a more desirable way of organizing an insurance company. By contrast, in developed countries, the conditions for the establishment of mutual insurance companies, without which good social policy cannot be imagined, are more favorable than joint stock companies. The issue of the safety of the 
performance of pension fund obligations in the future is also open. This is a major obstacle to the development of voluntary pension insurance, because although it is unlikely that the obligations of the fund or the insurer will be executed, this danger cannot be excluded. In the EU, current projects are aimed at establishing transnational rules for guaranteeing obligations under long-term insurance contracts. In some countries, schemes of guarantee already exist in the form of funds in which all insurers are paid in advance, which foresees the establishment of funds that are formed only in the event of a bankruptcy of the fund or insurance company. The NBS argues that the operations of these funds are safe considering that assets can only be invested in the safest and most liquid securities. If so, the question is why there is no guarantee that the fund's obligations will be executed regardless of the possible crash of their business ([7], p.121).

Undoubtedly, a sustainable pension system must be the result of comprehensive economic, sociological, demographic and other research. The rationale for the reform is to be implemented because there is an unfavorable relationship between the working and the dependent population and the aging of the population does not take into account the complexity of all the causes that led to problems in the functioning of Serbian pension insurance. The problem of a large number of 'dependent' population segments should not be solved by a brutal reform of the pension system, but by a more just distribution of social wealth, and by directing all potentials to economic growth and increasing employment. As for the aging of the population, a comparative study should be made to determine the situation in Serbia in relation to other countries.

The data on increased mortality of both pensioners and people who die in their best years of serious illnesses considers how many Serbian citizens will receive pensions, and how long they can use them ([10], p.122).

\section{REFORMS OF THE SERBIAN PENSION SYSTEM}

The purpose of the implementation of the Serbian pension reform is to establish a longterm sustainable system that provides greater social and financial security and a higher overall level of pensions.

The basic motive of the reform is to make the pension system resistant to demographic and economic shocks, as well as efficient, effective, and flexible in relation to the needs and preferences of individuals and less dependent on the state.

Compulsory pension and disability insurance in Serbia is based on current financing of pensions and includes the insurance of three basic types of risks: age, disability and death of the insured.

A compulsory component that provides the minimum age-appropriate income (absolute standard of living) is based on a minimum retirement sum, and the component that ensures the maintenance of income in age is based on the score system. Since the end of 2006, a part of the system has also been voluntary pension savings in private pension funds ([5], p.35).

This design of the pension system is the result of a comprehensive reform of the pension system in the 2001-2003 period. At the end of 2005, certain changes were made. The pension system component that provides an absolute living standard in Serbia is realized through a minimum pension. When s/he fulfills the conditions for retirement, those insured whose pension is below the legal level are entitled to a minimum pension. The retirement conditions are the appropriate age limit and minimum length of service. 
The minimum pension currently in Serbia is just over 13,221 dinars, i.e. about $20 \%$ of the average gross salary. Within the legal changes in the period from 2001 to 2003, a uniform minimum pension amount of $20 \%$ of the average salary was guaranteed, instead of the then multiple minimum pensions which depended on the length of service. By the end of 2005, the minimum pension was increased formally to $25 \%$ of the salary, but as a result of indexing twice a year, it ranged between $20 \%$ and $22 \%$. The minimum retirement amount is within the limits of the minimum or social retirement pensions of the countries in the region, and somewhat lower than the compensation of that type in highly developed countries ([9], p.35).

Due to an inclusion of the total working life, instead of the 10 most highly-paid years, a stronger link between the sum of the pension and the paid contributions is made, eliminating the spillover for those who made progress in their career or had a significantly higher salary in only one part of their work history. This method increases and more precisely determines the difference in the pension sum, depending on the length of service. The new 2003 law also stipulates that the retirement age is increased for over 40 years of service, which was not the case before, but with the idea of encouraging work as long as possible.

According to current legal solutions (from 2005), the retirement age increased gradually and in 2011 it reached 60 years for women and 65 for men, with a minimum of 15 years of service. This age limit was determined by multiple legal changes after 2000 .

One of the major reform movements in 2001 was the increase in the age limit from 55 to 58 for women and from 60 to 63 for men (at the same time the minimum age limit was shifted from 50 to 53 years).

\section{The legal framework for pension reforms in Serbia}

The mentioned pension system reform in Serbia was carried out in September 2005 by bringing the following laws:

- the Law on Amendments to the Law on Pension and Disability Insurance;

- the Law on Voluntary Pension Funds and Pension Plans;

- the Law on Payment of Contributions for pension and disability insurance for certain categories;

- the Law on the Public Debt of the Republic of Serbia on the takeover of obligations of the Republic Fund for pension and disability insurance of employees based on unpaid pensions;

- the Law on the Public Debt of the Republic of Serbia on the basis of assuming obligations of the Republic Fund for Pension and disability insurance of farmers arising from unpaid pensions and cash benefits ([12], 85/2005).

\section{The necessity of reforming the Serbian pension system}

The pension system reform is one of the most striking and, at the same time, the most sensitive issues of the overall reform processes of recent decades both in developed and transition countries. The long-term pressure of population aging and the prolongation of life expectancy, the need to reduce, or additionally, prevent poverty among the elderly, the need to reduce fiscal pressures and lower the cost of the labor force, and the inadequacy of certain pension schemes and solutions are strong drivers of the reforms. 
In Serbia, there are three categories of pensioners: old-age pensioners, those who were employed and paid a contribution to the pension insurance fund and need to exceed a certain age limit in order to be eligible for retirement; disability pensioners, who receive a pension regardless of their age, based on their state of health; and family pensioners, most often children whose parents have died, who are in full-time education, as well as widows or widowers, if supported by their spouses. Previously, there were three pension insurance funds: the employee fund, self-employed fund, and farmer fund, all of which were consolidated into a single fund at the beginning of 2008 .

Due to the unfavorable ratio of actively insured persons and pension beneficiaries, the state is compensating for pension benefits from the budget. Pension costs in our country account for $14 \%$ of the gross domestic product and are among the highest in the region. In order to pay out all pensions, the state of Serbia must allocate from the budget as much as $40 \%$ of the funds needed for the payment of pension benefits (in 2005 it was about 800 million Euros, or 65 billion dinars).

In transition countries, reforms were most often conceived with the support of the World Bank under the so-called three pillars. Typical reforms in the three-pillar model include parametric changes to the 1st pillar (the current, state PAYG system), the introduction of the 2nd pillar through mandatory additional savings of younger insurers in private pension funds and the development of voluntary pension insurance as the 3rd pillar of the pension system.

\section{Transfer of the $1^{\text {st }}$ pillar}

The 1st pillar is compulsory, it is financed by the principle of current income and expense (pay-as-you-go), the pension is pre-defined, and the revenues are provided by the state's taxation (contributions). This pillar is managed by the state, so management is centralized. Also, the 1st pillar provides a redistributive function - intergenerational solidarity.

Table 1 .Review of the age limits for a pension.

\begin{tabular}{|c|c|c|c|}
\hline $\begin{array}{c}\text { The year when } \\
\text { condition for an } \\
\text { old age pension } \\
\text { are met }\end{array}$ & Men & Women & $\begin{array}{c}\text { Minimum length } \\
\text { of service }\end{array}$ \\
\hline $\mathbf{2 0 0 6 , 2 0 0 7}$ & 63 & 58 & 20 \\
\hline $\mathbf{2 0 0 8}$ & 63,5 & 58,5 & 19 \\
\hline $\mathbf{2 0 0 9}$ & 64 & 59 & 18 \\
\hline $\mathbf{2 0 1 0}$ & 64,5 & 59 & 17 \\
\hline $\mathbf{2 0 1 1}$ & 65 & 60 & 15 \\
\hline $\mathbf{2 0 1 7}$ & 65 & 61,6 & 15 \\
\hline
\end{tabular}

Source: www.parlament.gov.rs. 


\section{Transfer of the $2^{\text {nd }}$ pillar}

The 2nd pillar represents mandatory savings managed by private pension funds. Managing this pillar of the pension system is usually decentralized to private computing. The 2 nd pillar pension depends on the contributions paid and the ability of the selected fund to increase them further, while the risk is borne by the user.

The 2nd pillar or compulsory private pension insurance exists in Croatia, Bulgaria, Macedonia, Poland, Slovakia and other countries. In the Czech Republic, Slovenia, and Ukraine, the 2nd pillar has not been formed, so that the structure of the pension system is the 1 st and 3rd pillars.

In the current reform of Serbia, it has been decided that the pension system relies on two components: the current financing of pensions (PAYG) organized within the state fund (1st pillar), to the development of voluntary old-age savings in private pension funds (3rd pillar). During the first wave of reforms, the idea that besides these two components in the pension system there were also mandatory savings in private pension funds, the so-called 2nd pillar, was discarded. Thus it can be concluded that even today the introduction of the 2nd pillar in Serbia is not recommended.

\section{Basic features of the $3^{\text {rd }}$ pillar}

The 3rd pillar represents voluntary savings managed by private pension funds, as well as a supplement to pensions from the 1 st and 2 nd pillars. In this model, the financial risk is borne by the user.

It should be noted that the 2004 Insurance Law envisaged voluntary pension insurance. The Law on Voluntary Pension Funds and Pension Plans, which is part of the aforementioned package of laws of September 2005, began to develop voluntary private pension insurance in Serbia ([13], 55/04 and 70/04).

Simultaneously with the reform of the state pension system, the adoption of the Law on Voluntary Pension Funds and Plans regulates private pension insurance, the so-called 3rd pillar model of the pension system. The essence of the proposed solutions is to create the conditions for the citizens to increase the pension income with pensions from the state pension fund by establishing satisfactory pension funds and pension plans.

Although it is estimated that the introduction of voluntary pension insurance is a very positive thing that will contribute to improving the functioning of the system as a whole, there are, however, certain objections. The National Bank of Serbia supervises the work of the management company for private pension funds ([12], 85/05).

The introduction of the 3rd pillar is not adequately followed in terms of marketing as well as training. This is important due to raising the awareness of the insured about the importance of saving in this way, and preparing pension funds for possible 2nd pillar introduction when they will have a much larger role (experience, management, marketing) and capital market development. The experiences of other countries have clearly shown that training and marketing are very important factors that will determine the effectiveness of introducing a voluntary pension insurance ([5], p.32). 
In Serbia, despite the establishment of voluntary pension funds, citizens are more likely to opt for life insurance as a way of saving for old age. Despite the necessity and priority of investing in pension funds, there have been no major developments yet since the establishment of the first funds. Voluntary pension insurance is considered savings through pension funds, because in the field of supplementary pensions, only the law on voluntary pension funds has been adopted ([11], p.3).

According to the data from the Statistical Office of the Pension and Disability Insurance Fund, in June 2017 there were 1,736,154 pensioners in Serbia, which are 5,917 less than the record number of 1,742,071 in February 2015. Reducing the number of pensioners is an expansive endeavor: demise was accelerated and the working-class inflow slowed down, so the number of pensioners decreased rapidly: by 809 in March, 886 in April, 1,719 in May, and in June the decrease was reduced to only 741 people (i.e. pension checks) compared to May.

The largest number of pensioners in Serbia is from the ranks of employees - 1,451,314, far fewer farmers - 212,273, while from the category of independent activities, as few as 72,567.

Private pension funds are one of the largest institutional investors in the world, but in Serbia, where they first arrived in November 2006, they were hardly known. According to the latest data from the National Bank of Serbia, the total value of all pension funds in the last five years has steadily increased, reaching only 12.45 billion dinars, or 120 million Euros in December 2011. When compared with almost 800 billion dinars deposited in banks by citizens, or 7.6 billion Euros, it is clear how much this type of investment is unpopular in our country.

The previous changes in the pension system of the Republic of Serbia have yielded significant results. Some World Bank research shows that deficits in the pension system would be 3 to 4 times higher without previously making changes, which is a very large shift in relation to the initial state ([4], p.18).

\section{Assessing the opinions of citizens}

For the purposes of this paper, a survey was conducted to assess the opinion of Belgrade residents towards the existing mandatory pension insurance and assess the attitude of the need for the implementation of additional systems.

The general hypothesis is: citizens are not satisfied with the current situation in the pension insurance system, they believe that the pension fund is empty and does not guarantee safe pensions. This means that the reforms implemented so far have not been sufficient and that reforms need to be continued.

The research was done on the territory of the city of Belgrade on a sample of 120 respondents. The statistical method dominated from the general scientific methods in this study, and the descriptive - survey-research - method was applied from specific research methods, since this variant of scientific description implies an active involvement of respondents in providing information on the phenomena that are the subject of the study, on the basis of which can enter the essence of a research subject and determine its condition, as well as detect causal relationships and relationships. The Statistical Package for Social Sciences was used for statistical data processing. The non-parametric statistical procedure Chi square test and contingency coefficient $\mathrm{C}$ were used for data processing. 
Nonparametric statistical procedures examine the significance of statistical indicators that apply regardless of whether the data is measured or counted and whether they are distributed regularly or differently. In other words, this means that they do not depend on the shape of the frequency distribution. The Chi-square test is a nonparametric statistical procedure, which means that qualitative (categorical) data is used in its calculation. It should be especially emphasized that other measurement units, other than frequency, are not considered for data processing using the Chi-square test.

Table 2. The compulsory pension insurance is excellent.

\begin{tabular}{|c|c|c|c|c|c|c|c|c|c|c|}
\hline \multirow{2}{*}{\multicolumn{2}{|c|}{\begin{tabular}{|c|}
$\begin{array}{c}\text { Social-andragogical } \\
\text { character. of respondents }\end{array}$ \\
\end{tabular}}} & \multicolumn{9}{|c|}{ Mandatory pension insurance is excellent } \\
\hline & & \multirow{2}{*}{$\begin{array}{l}1 \\
7\end{array}$} & \multirow{2}{*}{$\frac{2}{12}$} & \multirow{2}{*}{\begin{tabular}{r|}
3 \\
10
\end{tabular}} & \multirow{2}{*}{$\begin{array}{l}4 \\
5\end{array}$} & \multirow{2}{*}{\begin{tabular}{|r|}
5 \\
11
\end{tabular}} & \multicolumn{2}{|c|}{ IN TOTAL } & \multirow{2}{*}{$x^{2}$ i C } & \multirow[t]{2}{*}{ p } \\
\hline \multirow{4}{*}{ Pol } & 1 Males & & & & & & 45 & \multirow{4}{*}{$\begin{array}{c}120 \\
100 \%\end{array}$} & & \\
\hline & 1. Mnales & $5,8 \%$ & $10,0 \%$ & $8,3 \%$ & $4,2 \%$ & $9,2 \%$ & $37,5 \%$ & & \multirow{3}{*}{$\begin{aligned} x^{2} & =5,625 \\
C & =0,212\end{aligned}$} & \multirow{3}{*}{$\begin{array}{c}\mathrm{p}=0,229 \\
\mathrm{p}>0,05\end{array}$} \\
\hline & & 15 & 14 & 14 & 20 & 12 & 75 & & & \\
\hline & 2. Females & $12,5 \%$ & $11,7 \%$ & $11,7 \%$ & $16,7 \%$ & $10,0 \%$ & $62,5 \%$ & & & \\
\hline \multirow{6}{*}{$\begin{array}{c}\text { Year of } \\
\text { life }\end{array}$} & \multirow{2}{*}{ 1. Up to 35 years } & 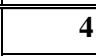 & $=$ & $\overline{79}$ & $\overline{12}$ & $\overline{\overline{8}}$ & 37 & \multirow{6}{*}{$\begin{array}{c}120 \\
100 \%\end{array}$} & \multirow{6}{*}{$\begin{aligned} x^{2} & =17,483 \\
C & =0,357\end{aligned}$} & \multirow{6}{*}{$\begin{array}{l}\mathrm{p}=0,025 \\
\mathrm{p}<0,05\end{array}$} \\
\hline & & $3,3 \%$ & $3,3 \%$ & $7,5 \%$ & $10,0 \%$ & $6,7 \%$ & $30,8 \%$ & & & \\
\hline & \multirow{2}{*}{ 2. 36-50 years } & 12 & 15 & 4 & 10 & 8 & 49 & & & \\
\hline & & $10,0 \%$ & $12,5 \%$ & $3,3 \%$ & $8,3 \%$ & $6,7 \%$ & $40,8 \%$ & & & \\
\hline & \multirow{2}{*}{ 3. Over 50 years } & 6 & 7 & 11 & 3 & 7 & 34 & & & \\
\hline & & $5,0 \%$ & $5,8 \%$ & $9,2 \%$ & $2,5 \%$ & $5,8 \%$ & $28,3 \%$ & & & \\
\hline \multirow{10}{*}{$\begin{array}{c}\text { Professio } \\
\text { nal } \\
\text { qualificat } \\
\text { ions }\end{array}$} & \multirow{2}{*}{$\begin{array}{l}\text { 1. Finished } \\
\text { elementary school }\end{array}$} & $\overline{\overline{0}}$ & $\bar{c}$ & 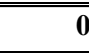 & $\overline{0}$ & $\overline{\overline{0}}$ & 0 & & \multirow{10}{*}{$\begin{aligned} x^{2} & =8,314 \\
C & =0,255\end{aligned}$} & \\
\hline & & $0,0 \%$ & $0,0 \%$ & $0,0 \%$ & $0,0 \%$ & $0,0 \%$ & $0,0 \%$ & & & \\
\hline & 2. Secondary & 5 & 10 & 5 & 7 & 9 & 36 & & & \\
\hline & education & $4,2 \%$ & $8,3 \%$ & $4,2 \%$ & $5,8 \%$ & $7,5 \%$ & $30,0 \%$ & & & \\
\hline & 3. Higher & 1 & 1 & 1 & $\mathbf{0}$ & 1 & 4 & 120 & & $\mathrm{p}=0,760$ \\
\hline & education & $0,8 \%$ & $0,8 \%$ & $0,8 \%$ & $0,0 \%$ & $0,8 \%$ & $3,3 \%$ & $100 \%$ & & $p>0,05$ \\
\hline & 4. High & 9 & 7 & 9 & 5 & 7 & 37 & & & \\
\hline & professional & $7,5 \%$ & $5,8 \%$ & $7,5 \%$ & $4,2 \%$ & $5,8 \%$ & $30,8 \%$ & & & \\
\hline & 5. Master / Doctor & 7 & 8 & 9 & 13 & 6 & 43 & & & \\
\hline & of Science & $5,8 \%$ & $6,7 \%$ & $7,5 \%$ & $10,8 \%$ & $5,0 \%$ & $35,8 \%$ & & & \\
\hline & & 8 & 8 & 8 & 11 & 7 & 42 & & & \\
\hline & 1. Up to 10 years & $6,7 \%$ & $6,7 \%$ & $6,7 \%$ & $9,2 \%$ & $5,8 \%$ & $35,0 \%$ & & & \\
\hline & 2. From 11 to 20 & 7 & 8 & 4 & 10 & 8 & 37 & & & \\
\hline Years of & years & $5,8 \%$ & $6,7 \%$ & $3,3 \%$ & $8,3 \%$ & $6,7 \%$ & $30,8 \%$ & 120 & $x^{2}=13,115$ & $\mathrm{p}=0,361$ \\
\hline service & 3. From 21 to 30 & 4 & 8 & 5 & 3 & 3 & 23 & $100 \%$ & $\mathrm{C}=0,314$ & $p>0,05$ \\
\hline & years & $3,3 \%$ & $6,7 \%$ & $4,2 \%$ & $2,5 \%$ & $2,5 \%$ & $19,2 \%$ & & & \\
\hline & & 3 & 2 & 7 & 1 & 5 & 18 & & & \\
\hline & D years & $2,5 \%$ & $1,7 \%$ & $5,8 \%$ & $0,8 \%$ & $4,2 \%$ & $15,0 \%$ & & & \\
\hline & & 17 & 18 & 13 & 18 & 17 & 83 & & & \\
\hline & 1. Worker & $14,2 \%$ & $15,0 \%$ & $10,8 \%$ & $15,0 \%$ & $14,2 \%$ & $69,2 \%$ & & & \\
\hline & 2. Operations & 2 & 8 & 5 & 4 & 5 & 19 & & & \\
\hline Workpla & Manager & $1,7 \%$ & $2,5 \%$ & $4,2 \%$ & $3,3 \%$ & $4,2 \%$ & $15,8 \%$ & 120 & $x^{2}=9,223$ & $\mathrm{p}=0,684$ \\
\hline ce & 3. Mid-level & 2 & 4 & 3 & 1 & 1 & 11 & $100 \%$ & $\mathrm{C}=0,267$ & $p>0,05$ \\
\hline & manager & $1,7 \%$ & $3,3 \%$ & $2,5 \%$ & $0,8 \%$ & $0,8 \%$ & $9,2 \%$ & & & \\
\hline & 4. Top & 1 & 1 & 3 & 2 & $\mathbf{0}$ & 7 & & & \\
\hline & Management & $0,8 \%$ & $0,8 \%$ & $2,5 \%$ & $1,7 \%$ & $0,0 \%$ & $5,8 \%$ & & & \\
\hline
\end{tabular}


According to the data in Table 2. it is evident that all independent variables are not significantly related to respondent attitudes about whether the compulsory pension insurance is excellent. Namely, the value of the Chi-square test and the contingency coefficient $\mathrm{C}$ show that gender $(\mathrm{x} 2=5.625, \mathrm{C}=0.212$ and $\mathrm{p}=0.229)$, profession $(\mathrm{x} 2=8.314, \mathrm{C}=0.255$ and $\mathrm{p}=0.760)$, work experience $(\mathrm{x} 2=13.115, \mathrm{C}=0.314$ and $\mathrm{p}=0.361)$, and the position of the respondents in the company $(\mathrm{x} 2=9.223, \mathrm{C}=0.267$ and $\mathrm{p}=0.684$ ) are not statistically significantly related to the stated attitude of the respondents (opinion: the mandatory pension insurance is excellent). This means that we do not have significant deviations in respect of the said position.

On the other hand, however, age $(\mathrm{x} 2=17.483, \mathrm{C}=0.357$ and $\mathrm{p}=0.025)$ is statistically significant with the view that mandatory pension insurance is excellent. In other words, this means that the respondents' answers were statistically significantly different with regard to age.

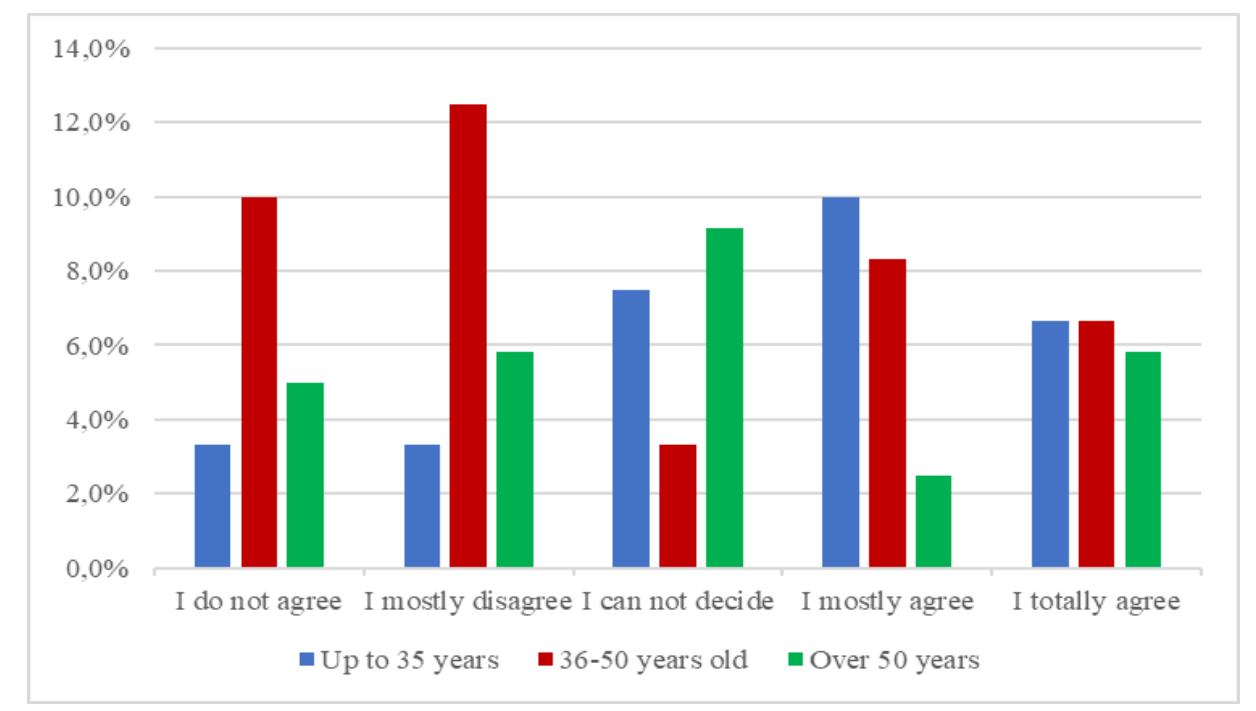

Graph 1. Agreement with the claim that compulsory pension insurance is excellent.

\section{Source: Author}

According to the results in graph 1 , the young generation places significantly more emphasis on compulsory pension insurance. The younger generation has much more trust in the pension fund than the middle-aged and elderly generation over 50, which indicates that this is a necessity of the modern era. Naturally, this would fully revitalize all the activities on this issue, which must be supported by the state. It is certain that this question cannot be solved by respondents and working organizations, and in the resolution of this issue, the maximum suspension of all state apparatus is expected. This attitude of the young generation is perhaps expected. That is exactly the life period when you need to think about solving the problem of pension insurance. It is interesting that the middle-aged generation disagrees with the view that compulsory pension insurance is excellent. In the elderly generation, one might say that the opinions are identical. 
Table 3. I expect a good pension which I can support myself with.

\begin{tabular}{|c|c|c|c|c|c|c|c|c|c|c|}
\hline \multirow{2}{*}{\multicolumn{2}{|c|}{$\begin{array}{c}\text { Social-andragogical } \\
\text { character. of respondents }\end{array}$}} & \multicolumn{9}{|c|}{ I expect a good pension from which I can live well } \\
\hline & & 1 & 2 & 3 & 4 & 5 & IN TOT & TAL & $x^{2}$ i C & $\mathbf{p}$ \\
\hline \multirow{4}{*}{ Pol } & \multirow{2}{*}{ 1. Males } & 15 & $\overline{7}$ & 8 & 4 & 11 & $\mid \overline{45 \mid}$ & \multirow{4}{*}{$\begin{array}{c}120 \\
100 \%\end{array}$} & \multirow{4}{*}{$\begin{array}{c}x^{2}=1,164 \\
C=0,098\end{array}$} & \multirow{4}{*}{$\begin{array}{c}\mathrm{p}=0,884 \\
\mathrm{p}>0,05\end{array}$} \\
\hline & & $12,5 \%$ & $5,8 \%$ & $6,7 \%$ & $3,3 \%$ & $9,2 \%$ & $37,5 \%$ & & & \\
\hline & \multirow{2}{*}{ 2. Females } & 29 & 14 & 9 & 7 & 16 & 75 & & & \\
\hline & & $24,2 \%$ & $11,7 \%$ & $7,5 \%$ & $5,8 \%$ & $13,3 \%$ & $62,5 \%$ & & & \\
\hline \multirow{6}{*}{$\begin{array}{l}\text { Year of } \\
\text { life }\end{array}$} & \multirow{2}{*}{ 1. Up to 35 years } & 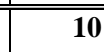 & $\overline{5}$ & 4 & 5 & 13 & 37 & \multirow{6}{*}{$\begin{array}{c}120 \\
100 \%\end{array}$} & \multirow{6}{*}{$\begin{aligned} x^{2} & =11,561 \\
C & =0,296\end{aligned}$} & \multirow{6}{*}{$\begin{array}{l}p=0,172 \\
p>0,05\end{array}$} \\
\hline & & $8,3 \%$ & $4,2 \%$ & $3,3 \%$ & $4,2 \%$ & $10,8 \%$ & $30,8 \%$ & & & \\
\hline & \multirow{2}{*}{ 2. 36-50 years } & 22 & 8 & 5 & 4 & 10 & 49 & & & \\
\hline & & $18,3 \%$ & $6,7 \%$ & $4,2 \%$ & $3,3 \%$ & $8,3 \%$ & $40,8 \%$ & & & \\
\hline & \multirow{2}{*}{ 3. Over 50 years } & 12 & 8 & 8 & 2 & 4 & 34 & & & \\
\hline & & $10,0 \%$ & $6,7 \%$ & $6,7 \%$ & $1,7 \%$ & $3,3 \%$ & $28,3 \%$ & & & \\
\hline \multirow{10}{*}{$\mid \begin{array}{c}\text { Professio } \\
\text { nal } \\
\text { qualificat } \\
\text { ions }\end{array}$} & \multirow{2}{*}{$\begin{array}{l}\text { 1. Finished } \\
\text { elementary school }\end{array}$} & $\overline{0}$ & $\overline{\overline{0}}$ & - 0 & 0 & 0 & 0 & \multirow{10}{*}{$\begin{array}{c}120 \\
100 \%\end{array}$} & \multirow{10}{*}{$\begin{aligned} x^{2} & =14,838 \\
\mathrm{C} & =0,332\end{aligned}$} & \multirow{10}{*}{$\begin{array}{l}\mathrm{p}=0,250 \\
\mathrm{p}>0,05\end{array}$} \\
\hline & & $0,0 \%$ & $0,0 \%$ & $0,0 \%$ & $0,0 \%$ & $0,0 \%$ & $0,0 \%$ & & & \\
\hline & \multirow{2}{*}{$\begin{array}{l}\text { 2. Secondary } \\
\text { education }\end{array}$} & 9 & 8 & 3 & 2 & 14 & 36 & & & \\
\hline & & $7,5 \%$ & $6,7 \%$ & $2,5 \%$ & $1,7 \%$ & $11,7 \%$ & $30,0 \%$ & & & \\
\hline & \multirow{2}{*}{$\begin{array}{l}\text { 3. Higher } \\
\text { education }\end{array}$} & 1 & 1 & 1 & $\mathbf{0}$ & 1 & 4 & & & \\
\hline & & $0,8 \%$ & $0,8 \%$ & $0,8 \%$ & $0,0 \%$ & $0,8 \%$ & $3,3 \%$ & & & \\
\hline & \multirow{2}{*}{\begin{tabular}{|l|} 
4. High \\
professional
\end{tabular}} & 19 & 5 & 5 & 3 & 5 & 37 & & & \\
\hline & & $15,8 \%$ & $4,2 \%$ & $4,2 \%$ & $2,5 \%$ & $4,2 \%$ & $30,8 \%$ & & & \\
\hline & \multirow{2}{*}{$\begin{array}{l}\text { 5. Master / Doctor } \\
\text { of Science }\end{array}$} & 15 & 7 & 8 & 6 & 7 & 43 & & & \\
\hline & & $12,5 \%$ & $5,8 \%$ & $6,7 \%$ & $5,0 \%$ & $5,8 \%$ & $35,8 \%$ & & & \\
\hline \multirow{8}{*}{$\begin{array}{l}\text { Years of } \\
\text { service }\end{array}$} & & 17 & $\overline{76}$ & 4 & 3 & 12 & 42 & & & \\
\hline & 1. Up to 10 years & $14,2 \%$ & $5,0 \%$ & $3,3 \%$ & $2,5 \%$ & $10,0 \%$ & $35,0 \%$ & & & \\
\hline & 2. From 11 to 20 & 13 & 5 & 6 & 5 & 8 & 37 & & & \\
\hline & years & $10,8 \%$ & $4,2 \%$ & $5,0 \%$ & $4,2 \%$ & $6,7 \%$ & $30,8 \%$ & 120 & $x^{2}=20,345$ & $\mathrm{p}=0,061$ \\
\hline & 3. From 21 to 30 & 11 & 7 & 0 & 1 & 4 & 23 & $100 \%$ & $\mathrm{C}=0,381$ & $p>0,05$ \\
\hline & years & $9,2 \%$ & $5,8 \%$ & $0,0 \%$ & $0,8 \%$ & $3,3 \%$ & $19,2 \%$ & & & \\
\hline & & 3 & 3 & 7 & 2 & 3 & 18 & & & \\
\hline & 4. Over 30 years & $2,5 \%$ & $2,5 \%$ & $5,8 \%$ & $1,7 \%$ & $2,5 \%$ & $15,0 \%$ & & & \\
\hline & & 30 & 12 & 9 & 7 & 25 & 83 & & & \\
\hline & 1. Worker & $25,0 \%$ & $10,0 \%$ & $7,5 \%$ & $5,8 \%$ & $20,8 \%$ & $69,2 \%$ & & & \\
\hline & 2. Operations & 6 & 5 & 5 & 2 & 1 & 19 & & & \\
\hline Workpla & Manager & $5,0 \%$ & $4,2 \%$ & $4,2 \%$ & $1,7 \%$ & $0,8 \%$ & $15,8 \%$ & 120 & $x^{2}=16,197$ & $p=0,182$ \\
\hline ce & 3. Mid-level & 5 & 3 & 2 & 0 & 1 & 11 & $100 \%$ & $\mathrm{C}=0,245$ & $p>0,05$ \\
\hline & manager & $4,2 \%$ & $2,5 \%$ & $1,7 \%$ & $0,0 \%$ & $0,8 \%$ & $9,2 \%$ & & & \\
\hline & 4. Top & 3 & 1 & 1 & 2 & 0 & 7 & & & \\
\hline & Management & $2,5 \%$ & $0,8 \%$ & $0,8 \%$ & $1,7 \%$ & $0,0 \%$ & $5,8 \%$ & & & \\
\hline
\end{tabular}

\section{Source: Author}

According to the data in Table 3, we see that all independent variables are not significantly related to the views of the respondents about the pension they expect. Namely, the value of the Chi-square test and the contingency coefficient $\mathrm{C}$ show that gender $(\mathrm{x} 2=1.164, \mathrm{C}=0.098$ and $\mathrm{p}=0.884)$, age $(\mathrm{x} 2=11.561, \mathrm{C}=0.296$ and $\mathrm{p}=0.172)$, profession $(\mathrm{x} 2=14.838, \mathrm{C}=0.332$ and $\mathrm{p}=0.250)$, work experience $(\mathrm{x} 2=20.345, \mathrm{C}=0.382$ and $\mathrm{p}=0.061)$ and the position of the respondents in the company ( $\mathrm{x} 2=16.197, \mathrm{C}=0.245$ and $\mathrm{p}=0.182$ ) were not significantly related to the stated attitude of the respondent (opinion: mandatory pension insurance is excellent). 
This means that we have no significant deviations in respect of the said position. Based on the data from the table, we can conclude that regardless of gender, age, professional qualifications, working experience and position in the company, most respondents disagree with the view that they expect a good pension from which they will be able to live well.

Table 4. A pension fund guarantees secure pensions.

\begin{tabular}{|c|c|c|c|c|c|c|c|c|c|c|}
\hline \multirow{2}{*}{\multicolumn{2}{|c|}{$\begin{array}{c}\text { Social-andragogical } \\
\text { character. of respondents }\end{array}$}} & \multicolumn{9}{|c|}{ Pension fund guarantees safe pensions } \\
\hline & & 1 & 2 & 3 & 4 & 5 & IN TC & OTAL & $x^{2}$ i C & $\mathbf{p}$ \\
\hline \multirow{4}{*}{ Pol } & \multirow{2}{*}{ 1. Males } & 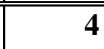 & 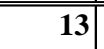 & 13 & 5 & 10 & 45 & \multirow{4}{*}{$\begin{array}{l}120 \\
100 \%\end{array}$} & \multirow{4}{*}{$\begin{aligned} x^{2} & =9,681 \\
C & =0,273\end{aligned}$} & \multirow{4}{*}{$\begin{array}{l}\mathrm{p}=0,046 \\
\mathrm{p}<0,05\end{array}$} \\
\hline & & $3,3 \%$ & $10,8 \%$ & $10,8 \%$ & $4,2 \%$ & $8,3 \%$ & $37,5 \%$ & & & \\
\hline & \multirow{2}{*}{ 2. Females } & 20 & 18 & 16 & 14 & 7 & 75 & & & \\
\hline & & $16,7 \%$ & $15,0 \%$ & $13,3 \%$ & $11,7 \%$ & $5,8 \%$ & $62,5 \%$ & & & \\
\hline \multirow{6}{*}{$\begin{array}{l}\text { Year of } \\
\text { life }\end{array}$} & \multirow{2}{*}{ 1. Up to 35 years } & 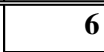 & 8 & 11 & 7 & 5 & 37 & \multirow{6}{*}{$\begin{array}{c}120 \\
100 \%\end{array}$} & \multirow{6}{*}{$\begin{array}{c}x^{2}=6,890 \\
\mathrm{C}=0,233\end{array}$} & \multirow{6}{*}{$\begin{array}{l}\mathrm{p}=0,549 \\
\mathrm{p}>0,05\end{array}$} \\
\hline & & $5,0 \%$ & $6,7 \%$ & $9,2 \%$ & $5,8 \%$ & $4,2 \%$ & $30,8 \%$ & & & \\
\hline & \multirow{2}{*}{ 2. 36-50 years } & 8 & 13 & 10 & 8 & 10 & 49 & & & \\
\hline & & $6,7 \%$ & $10,8 \%$ & $8,3 \%$ & $6,7 \%$ & $8,3 \%$ & $40,8 \%$ & & & \\
\hline & \multirow{2}{*}{ 3. Over 50 years } & 10 & 10 & 8 & 4 & 2 & 34 & & & \\
\hline & & $8,3 \%$ & $8,3 \%$ & $6,7 \%$ & $3,3 \%$ & $1,7 \%$ & $28,3 \%$ & & & \\
\hline \multirow{10}{*}{$\begin{array}{c}\text { Professio } \\
\text { nal } \\
\text { qualificat } \\
\text { ions }\end{array}$} & \multirow{2}{*}{$\begin{array}{l}\text { 1. Finished } \\
\text { elementary school }\end{array}$} & $\overline{0}$ & ( & - & 0 & 0 & $\mathbf{0}$ & \multirow{10}{*}{$\begin{array}{c}120 \\
100 \%\end{array}$} & \multirow{10}{*}{$\begin{aligned} x^{2} & =11,845 \\
\mathrm{C} & =0,300\end{aligned}$} & \multirow{10}{*}{$\begin{array}{l}\mathrm{p}=0,458 \\
\mathrm{p}>0,05\end{array}$} \\
\hline & & $0,0 \%$ & $0,0 \%$ & $0,0 \%$ & $0,0 \%$ & $0,0 \%$ & $0,0 \%$ & & & \\
\hline & \multirow{2}{*}{$\begin{array}{l}\text { 2. Secondary } \\
\text { education }\end{array}$} & 6 & 5 & 8 & 10 & 7 & 36 & & & \\
\hline & & $5,0 \%$ & $4,2 \%$ & $6,7 \%$ & $8,3 \%$ & $5,8 \%$ & $30,0 \%$ & & & \\
\hline & \multirow{2}{*}{$\begin{array}{l}\text { 3. Higher } \\
\text { education }\end{array}$} & 1 & 1 & 1 & 0 & 1 & 4 & & & \\
\hline & & $0,8 \%$ & $0,8 \%$ & $0,8 \%$ & $0,0 \%$ & $0,8 \%$ & $3,3 \%$ & & & \\
\hline & \multirow{2}{*}{\begin{tabular}{|l} 
4. High \\
professional
\end{tabular}} & 7 & 10 & 9 & 5 & 6 & 37 & & & \\
\hline & & $5,8 \%$ & $8,3 \%$ & $7,5 \%$ & $4,2 \%$ & $5,0 \%$ & $30,8 \%$ & & & \\
\hline & \multirow{2}{*}{$\begin{array}{l}\text { 5. Master / Doctor } \\
\text { of Science }\end{array}$} & 10 & 15 & 11 & 4 & 3 & 43 & & & \\
\hline & & $8,3 \%$ & $12,5 \%$ & $9,2 \%$ & $3,3 \%$ & $2,5 \%$ & $35,8 \%$ & & & \\
\hline \multirow{8}{*}{$\begin{array}{l}\text { Years of } \\
\text { service }\end{array}$} & 1 & 7 & 7 & 12 & 9 & 7 & 42 & & & \\
\hline & 1. Op to io years & $5,8 \%$ & $5,8 \%$ & $10,0 \%$ & $7,5 \%$ & $5,8 \%$ & $35,0 \%$ & & & \\
\hline & 2. From 11 to 20 & 7 & 11 & 8 & 3 & 8 & 37 & & & \\
\hline & years & $5,8 \%$ & $9,2 \%$ & $6,7 \%$ & $2,5 \%$ & $6,7 \%$ & $30,8 \%$ & 120 & $x^{2}=18,315$ & $p=0,106$ \\
\hline & 3. From 21 to 30 & 6 & 7 & 3 & 7 & 0 & 23 & $100 \%$ & $\mathrm{C}=0,364$ & $p>0,05$ \\
\hline & years & $5,0 \%$ & $5,8 \%$ & $2,5 \%$ & $5,8 \%$ & $0,0 \%$ & $19,2 \%$ & & & \\
\hline & & 4 & 6 & 6 & $\mathbf{0}$ & 2 & 18 & & & \\
\hline & 4. Over 30 years & $3,3 \%$ & $5,0 \%$ & $5,0 \%$ & $0,0 \%$ & $1,7 \%$ & $15,0 \%$ & & & \\
\hline & $1 \mathbf{w}$ & 13 & 20 & 20 & 16 & 14 & 83 & & & \\
\hline & 1. Worker & \begin{tabular}{|l|}
$10,8 \%$ \\
\end{tabular} & $16,7 \%$ & $16,7 \%$ & $13,3 \%$ & $11,7 \%$ & $69,2 \%$ & & & \\
\hline & 2. Operations & 5 & 6 & 4 & 2 & 2 & 19 & & & \\
\hline Workpla & Manager & $4,2 \%$ & $5,0 \%$ & $3,3 \%$ & $1,7 \%$ & $1,7 \%$ & $15,8 \%$ & 120 & $x^{2}=9,193$ & $\mathrm{p}=0,686$ \\
\hline ce & 3. Mid-level & 3 & 3 & 4 & 0 & 1 & 11 & $100 \%$ & $\mathrm{C}=0,267$ & $\mathrm{p}>0,05$ \\
\hline & manager & $2,5 \%$ & $2,5 \%$ & $3,3 \%$ & $0,0 \%$ & $0,8 \%$ & $9,2 \%$ & & & \\
\hline & 4. Top & 3 & 2 & 1 & 1 & 0 & 7 & & & \\
\hline & Management & $2,5 \%$ & $1,7 \%$ & $0,8 \%$ & $0,8 \%$ & $0,0 \%$ & $5,8 \%$ & & & \\
\hline
\end{tabular}

Source: Author 
According to the data in Table 4, not all independent variables are significantly related to the respondents' attitudes about whether the compulsory pension insurance is excellent. Namely, the value of the Chi-square test and the coefficient of contingency $\mathrm{C}$ show that age $(\mathrm{x} 2=6.890, \mathrm{C}=0.267$ and $\mathrm{p}=0.684)$, profession $(\mathrm{x} 2=11.845, \mathrm{C}=0.300$ and $\mathrm{p}=0.458)$, work experience $(\mathrm{x} 2=18.315, \mathrm{C}=0.364$ and $\mathrm{p}=0.106)$ and the position of the respondents in the company ( $\mathrm{x} 2=9.193, \mathrm{C}=0.267$ and $\mathrm{p}=0.686$ ) were not statistically significantly related to the stated attitude of the respondents (opinion: the pension fund guarantees safe pensions). This means that we have no significant deviations in respect of the said position. Most respondents share the view that the pension fund does not guarantee a secure pension.

The independent variable of gender $(\mathrm{x} 2=8.672, \mathrm{C}=0.155$ and $\mathrm{p}=0.070)$ is statistically significant with the view that the pension fund guarantees safe pensions. In other words, this means that the answers of the respondents are statistically significant in terms of gender.

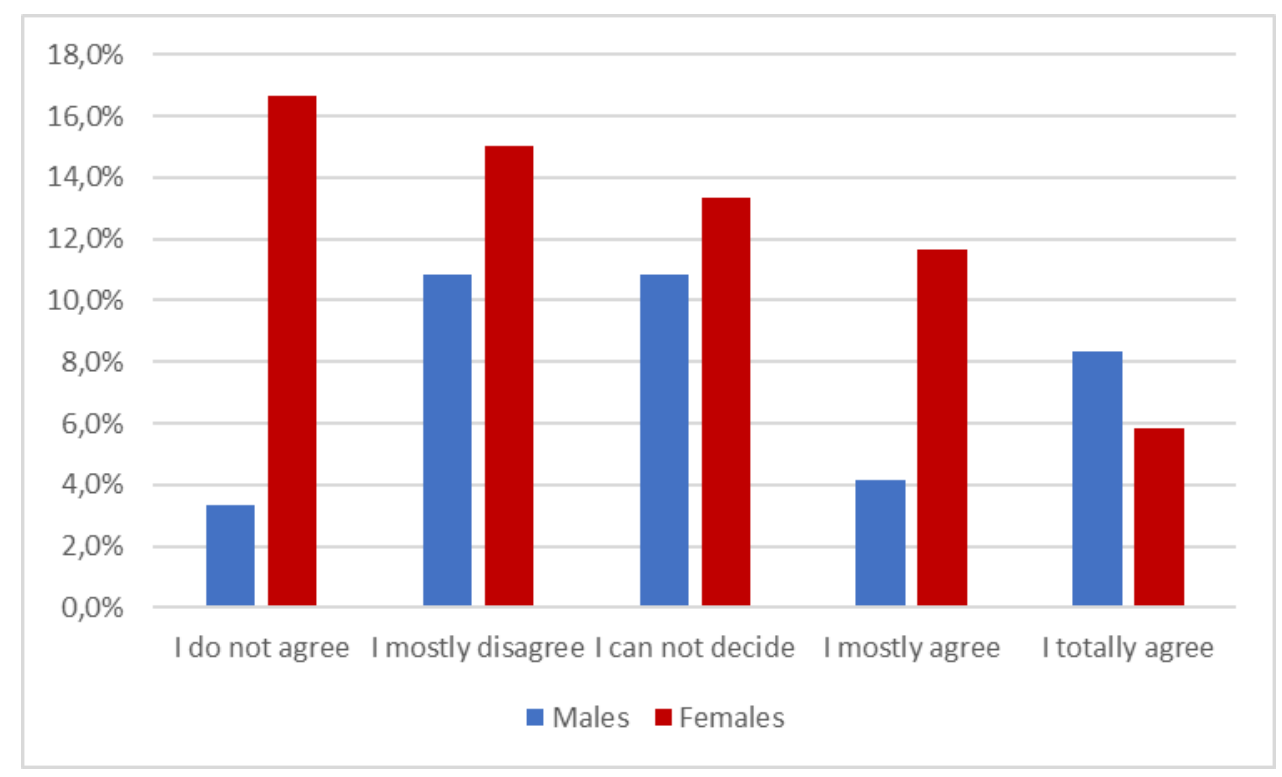

Graph 2. Agreement with the claim that the pension fund guarantees secure pensions

\section{Source: Author}

By analyzing the data from Graph 2, we can conclude that the claim that the pension fund guarantees secure pensions does not agree with the majority of the respondents regardless of gender, but female respondents are predominant. This is perhaps understandable because women have a more cautious attitude to existence. 
Table 5. A reform of the pension system is necessary.

\begin{tabular}{|c|c|c|c|c|c|c|c|c|c|c|}
\hline \multirow{2}{*}{\multicolumn{2}{|c|}{$\begin{array}{c}\text { Social-andragogical } \\
\text { character. of respondents }\end{array}$}} & \multicolumn{9}{|c|}{ It is necessary to reform the mandatory pension insurance } \\
\hline & & 1 & 2 & 3 & 4 & 5 & IN TOT & TAL & $x^{2}$ i C & $\mathbf{p}$ \\
\hline \multirow{4}{*}{ Pol } & \multirow{2}{*}{ 1. Males } & $\overline{00}$ & 1 & $\overline{c 6}$ & 1212 & 26 & 45 & \multirow{4}{*}{$\begin{array}{c}120 \\
100 \%\end{array}$} & \multirow{4}{*}{$\begin{aligned} x^{2} & =4,088 \\
C & =0,182\end{aligned}$} & \multirow{4}{*}{$\begin{array}{l}\mathrm{p}=0,334 \\
\mathrm{p}>0,05\end{array}$} \\
\hline & & $0,0 \%$ & $0,8 \%$ & $5,0 \%$ & $10,0 \%$ & $21,7 \%$ & $37,5 \%$ & & & \\
\hline & \multirow{2}{*}{ 2. Females } & 2 & $\mathbf{0}$ & 9 & 14 & 50 & 75 & & & \\
\hline & & $1,7 \%$ & $0,0 \%$ & $7,5 \%$ & $11,7 \%$ & $41,7 \%$ & $62,5 \%$ & & & \\
\hline \multirow{6}{*}{$\begin{array}{l}\text { Year of } \\
\text { life }\end{array}$} & \multirow{2}{*}{ 1. Up to 35 years } & 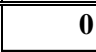 & (0 & 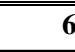 & 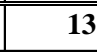 & 18 & 37 & \multirow{6}{*}{$\begin{array}{c}120 \\
100 \%\end{array}$} & \multirow{6}{*}{$\begin{aligned} x^{2} & =14,786 \\
C & =0,331\end{aligned}$} & \multirow{6}{*}{$\begin{array}{l}p=0,063 \\
p>0,05\end{array}$} \\
\hline & & $0,0 \%$ & $0,0 \%$ & $5,0 \%$ & $10,8 \%$ & $15,0 \%$ & $30,8 \%$ & & & \\
\hline & \multirow{2}{*}{ 2. 36-50 years } & $\mathbf{0}$ & 0 & 5 & 8 & 36 & 49 & & & \\
\hline & & $0,0 \%$ & $0,0 \%$ & $4,2 \%$ & $6,7 \%$ & $30,0 \%$ & $40,8 \%$ & & & \\
\hline & \multirow{2}{*}{ 3. Over 50 years } & 2 & 1 & 4 & 5 & 22 & 34 & & & \\
\hline & & $1,7 \%$ & $0,8 \%$ & $3,3 \%$ & $4,2 \%$ & $18,3 \%$ & $28,3 \%$ & & & \\
\hline \multirow{10}{*}{$\mid \begin{array}{c}\text { Professio } \\
\text { nal } \\
\text { qualificat } \\
\text { ions }\end{array}$} & \multirow{2}{*}{$\begin{array}{l}\text { 1. Finished } \\
\text { elementary school }\end{array}$} & $\overline{0}$ & 0 & $\mathbf{0}$ & $\overline{0}$ & 0 & o & \multirow{10}{*}{120} & \multirow{10}{*}{$\begin{aligned} x^{2} & =8,335 \\
C & =0,256\end{aligned}$} & \multirow{10}{*}{$\begin{array}{l}p=0,754 \\
p>0,05\end{array}$} \\
\hline & & $0,0 \%$ & $0,0 \%$ & $0,0 \%$ & $0,0 \%$ & $0,0 \%$ & $0,0 \%$ & & & \\
\hline & \multirow{2}{*}{$\begin{array}{l}\text { 2. Secondary } \\
\text { education }\end{array}$} & 2 & $\mathbf{0}$ & 4 & 9 & 21 & 36 & & & \\
\hline & & $1,7 \%$ & $0,0 \%$ & $3,3 \%$ & $7,5 \%$ & $17,5 \%$ & $30,0 \%$ & & & \\
\hline & \multirow{2}{*}{$\begin{array}{l}\text { 3. Higher } \\
\text { education }\end{array}$} & $\mathbf{0}$ & $\mathbf{0}$ & 1 & $\mathbf{0}$ & 3 & 4 & & & \\
\hline & & $0,0 \%$ & $0,0 \%$ & $0,8 \%$ & $0,0 \%$ & $2,5 \%$ & $3,3 \%$ & & & \\
\hline & \multirow{2}{*}{$\begin{array}{l}\text { 4. High } \\
\text { professional }\end{array}$} & $\mathbf{0}$ & $\mathbf{0}$ & 5 & 8 & 24 & 37 & & & \\
\hline & & $0,0 \%$ & $0,0 \%$ & $4,2 \%$ & $6,7 \%$ & $20,0 \%$ & $30,8 \%$ & & & \\
\hline & \multirow{2}{*}{$\begin{array}{l}\text { 5. Master / Doctor } \\
\text { of Science }\end{array}$} & $\mathbf{0}$ & 1 & 5 & 9 & 28 & 43 & & & \\
\hline & & $0,0 \%$ & $0,8 \%$ & $4,2 \%$ & $7,5 \%$ & $23,3 \%$ & $35,8 \%$ & & & \\
\hline \multirow{8}{*}{$\begin{array}{l}\text { Years of } \\
\text { service }\end{array}$} & & $\overline{\mathbf{0}}$ & $\mathbf{0}$ & 6 & 15 & 21 & 42 & & & \\
\hline & 1 & $0,0 \%$ & $0,0 \%$ & $5,0 \%$ & $12,5 \%$ & $17,5 \%$ & $35,0 \%$ & & & \\
\hline & 2. From 11 to 20 & $\mathbf{0}$ & 0 & 5 & 4 & 28 & 37 & & & \\
\hline & years & $0,0 \%$ & $0,0 \%$ & $4,2 \%$ & $3,3 \%$ & $23,3 \%$ & $30,8 \%$ & 120 & $x^{2}=20,106$ & $\mathrm{p}=0,065$ \\
\hline & 3. From 21 to 30 & 1 & 0 & 1 & 4 & 17 & 23 & $100 \%$ & $\mathrm{C}=0,379$ & $p>0,05$ \\
\hline & & $0,8 \%$ & $0,0 \%$ & $0,8 \%$ & $3,3 \%$ & $14,2 \%$ & $19,2 \%$ & & & \\
\hline & & 1 & 1 & 3 & 3 & 10 & 18 & & & \\
\hline & 4. Over 30 years & $0,8 \%$ & $0,8 \%$ & $2,5 \%$ & $2,5 \%$ & $8,3 \%$ & $15,0 \%$ & & & \\
\hline & & 2 & 1 & 10 & 19 & 51 & 83 & & & \\
\hline & 1. Worker & $1,7 \%$ & $0,8 \%$ & $8,3 \%$ & $15,8 \%$ & $42,5 \%$ & $69,2 \%$ & & & \\
\hline & 2. Operations & $\mathbf{0}$ & $\mathbf{0}$ & 3 & 4 & 12 & 19 & & & \\
\hline Workpla & Manager & $0,0 \%$ & $0,0 \%$ & $2,5 \%$ & $3,3 \%$ & $10,0 \%$ & $15,8 \%$ & 120 & $x^{2}=3,573$ & $\mathrm{p}=0,990$ \\
\hline ce & 3. Mid-level & $\mathbf{0}$ & 0 & 2 & 2 & 7 & 11 & $100 \%$ & $\mathrm{C}=0,170$ & $p>0,05$ \\
\hline & manager & $0,0 \%$ & $0,0 \%$ & $1,7 \%$ & $1,7 \%$ & $5,8 \%$ & $9,2 \%$ & & & \\
\hline & 4. Top & $\mathbf{0}$ & $\mathbf{0}$ & $\mathbf{0}$ & 1 & 6 & 7 & & & \\
\hline & Management & $0,0 \%$ & $0,0 \%$ & $0,0 \%$ & $0,8 \%$ & $5,0 \%$ & $5,8 \%$ & & & \\
\hline
\end{tabular}

\section{Source: Author}

According to the data in Table 5, we see that all independent variables are not significantly related to the respondents' attitudes about the necessity of reforming compulsory pension insurance. The value of the Chi-square test and the contingency coefficient $\mathrm{C}$ show that gender ( $\mathrm{x} 2=4.088, \mathrm{C}=0.182$ and $\mathrm{p}=0.334)$, age $(\mathrm{x} 2=14.786, \mathrm{C}=0.331$ and $\mathrm{p}=0.063)$, profession $(\mathrm{x} 2$ $=8.335, \mathrm{C}=0.256$ and $\mathrm{p}=0.754)$, work experience $(\mathrm{x} 2=20.106, \mathrm{C}=0.379$ and $\mathrm{p}=0.065)$ and the position in the company $(\mathrm{x} 2=3.573, \mathrm{C}=0.170$ and $\mathrm{p}=0.990)$ were not significantly related to the above respondents. This means that we have no significant deviations in respect of the said 
position. Based on the data from the table, we can conclude that regardless of gender, age, professional qualifications, working experience and position in the company, most respondents agree with the view that a mandatory pension insurance reform is necessary.

Table 6. A reform of compulsory pension insurance can be realized.

\begin{tabular}{|c|c|c|c|c|c|c|c|c|c|c|}
\hline \multirow{2}{*}{\multicolumn{2}{|c|}{$\begin{array}{c}\text { Social-andragogical } \\
\text { character. of respondents }\end{array}$}} & \multicolumn{9}{|c|}{ Reform of compulsory pension insurance can be realized } \\
\hline & & 1 & 2 & 3 & 4 & 5 & IN TOT & TAL & $x^{2}$ i C & $\mathbf{p}$ \\
\hline \multirow{4}{*}{ Pol } & \multirow{2}{*}{ 1. Males } & 2 & $\overline{\mathbf{0}}$ & 13 & 16 & 14 & 45 & \multirow{4}{*}{$\begin{array}{c}120 \\
100 \%\end{array}$} & \multirow{4}{*}{$\begin{array}{c}x^{2}=5,761 \\
C=0,214\end{array}$} & \multirow{4}{*}{$\begin{array}{l}\mathrm{p}=0,218 \\
\mathrm{p}>0,05\end{array}$} \\
\hline & & $1,7 \%$ & $0,0 \%$ & $10,8 \%$ & $13,3 \%$ & $11,7 \%$ & $37,5 \%$ & & & \\
\hline & \multirow{2}{*}{ 2. Females } & 2 & 6 & 24 & 17 & 26 & 75 & & & \\
\hline & & $1,7 \%$ & $5,0 \%$ & $20,0 \%$ & $14,2 \%$ & $21,7 \%$ & $62,5 \%$ & & & \\
\hline \multirow{6}{*}{$\begin{array}{l}\text { Year of } \\
\text { life }\end{array}$} & \multirow{2}{*}{ 1. Up to 35 years } & 3 & 1 & 14 & 12 & 7 & 37 & \multirow{6}{*}{$\begin{array}{c}120 \\
100 \%\end{array}$} & \multirow{6}{*}{$\begin{aligned} x^{2} & =10,652 \\
\mathrm{C} & =0,286\end{aligned}$} & \multirow{6}{*}{$\begin{array}{c}\mathrm{p}=0,222 \\
\mathrm{p}>0,05\end{array}$} \\
\hline & & $2,5 \%$ & $0,8 \%$ & $11,7 \%$ & $10,0 \%$ & $5,8 \%$ & $30,8 \%$ & & & \\
\hline & \multirow{2}{*}{ 2. 36-50 years } & $\mathbf{0}$ & 4 & 13 & 13 & 19 & 49 & & & \\
\hline & & $0,0 \%$ & $3,3 \%$ & $10,8 \%$ & $10,8 \%$ & $15,8 \%$ & $40,8 \%$ & & & \\
\hline & \multirow{2}{*}{ 3. Over 50 years } & 1 & 1 & 10 & 8 & 14 & 34 & & & \\
\hline & & $0,8 \%$ & $0,8 \%$ & $8,3 \%$ & $6,7 \%$ & $11,7 \%$ & $28,3 \%$ & & & \\
\hline \multirow{10}{*}{$\begin{array}{c}\text { Professio } \\
\text { nal } \\
\text { qualificat } \\
\text { ions }\end{array}$} & \multirow{2}{*}{\begin{tabular}{|l|} 
1. Finished \\
elementary school
\end{tabular}} & 0 & $\overline{\mathbf{0}}$ & "0| & 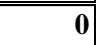 & $\overline{0}$ & "0| & \multirow{10}{*}{$\begin{array}{c}120 \\
100 \%\end{array}$} & \multirow{10}{*}{$\begin{aligned} x^{2} & =17,575 \\
\mathrm{C} & =0,357\end{aligned}$} & \multirow{10}{*}{$\begin{array}{l}\mathrm{p}=0,129 \\
\mathrm{p}>0,05\end{array}$} \\
\hline & & $0,0 \%$ & $0,0 \%$ & $0,0 \%$ & $0,0 \%$ & $0,0 \%$ & $0,0 \%$ & & & \\
\hline & \multirow{2}{*}{$\begin{array}{l}\text { 2. Secondary } \\
\text { education }\end{array}$} & $\mathbf{0}$ & 1 & 10 & 9 & 16 & 36 & & & \\
\hline & & $0,0 \%$ & $0,8 \%$ & $8,3 \%$ & $7,5 \%$ & $13,3 \%$ & $30,0 \%$ & & & \\
\hline & \multirow{2}{*}{$\begin{array}{l}\text { 3. Higher } \\
\text { education }\end{array}$} & $\mathbf{0}$ & $\mathbf{0}$ & 2 & 0 & 2 & 4 & & & \\
\hline & & $0,0 \%$ & $0,0 \%$ & $1,7 \%$ & $0,0 \%$ & $1,7 \%$ & $3,3 \%$ & & & \\
\hline & \multirow{2}{*}{\begin{tabular}{|l|} 
4. High \\
professional
\end{tabular}} & 0 & 2 & 16 & 8 & 11 & 37 & & & \\
\hline & & $0,0 \%$ & $1,7 \%$ & $13,3 \%$ & $6,7 \%$ & $9,2 \%$ & $30,8 \%$ & & & \\
\hline & \multirow{2}{*}{$\begin{array}{l}\text { 5. Master / Doctor } \\
\text { of Science }\end{array}$} & 4 & 3 & 9 & 16 & 11 & 43 & & & \\
\hline & & $3,3 \%$ & $2,5 \%$ & $7,5 \%$ & $13,3 \%$ & $9,2 \%$ & $35,8 \%$ & & & \\
\hline \multirow{8}{*}{$\begin{array}{l}\text { Years of } \\
\text { service }\end{array}$} & 1. & 3 & 2 & 13 & 14 & 10 & 42 & & & \\
\hline & 1. Up to 10 years & $2,5 \%$ & $1,7 \%$ & $10,8 \%$ & $11,7 \%$ & $8,3 \%$ & $35,0 \%$ & & & \\
\hline & 2. From 11 to 20 & $\mathbf{0}$ & 2 & 13 & 7 & 15 & 37 & & & \\
\hline & years & $0,0 \%$ & $1,7 \%$ & $10,8 \%$ & $5,8 \%$ & $12,5 \%$ & $30,8 \%$ & 120 & $x^{2}=11,318$ & $\mathrm{p}=0,502$ \\
\hline & 3. From 21 to 30 & $\mathbf{0}$ & 2 & 6 & 5 & 10 & 23 & $100 \%$ & $\mathrm{C}=0,294$ & $p>0,05$ \\
\hline & years & $0,0 \%$ & $1,7 \%$ & $5,0 \%$ & $4,2 \%$ & $8,3 \%$ & $19,2 \%$ & & & \\
\hline & & 1 & $\mathbf{0}$ & 5 & 7 & 5 & 18 & & & \\
\hline & 0 years & $0,8 \%$ & $0,0 \%$ & $4,2 \%$ & $5,8 \%$ & $4,2 \%$ & $15,0 \%$ & & & \\
\hline & & 3 & $\overline{2}$ & 25 & 25 & 28 & 83 & & & \\
\hline & 1. Worker & $2,5 \%$ & $1,7 \%$ & $20,8 \%$ & $20,8 \%$ & $23,3 \%$ & $69,2 \%$ & & & \\
\hline & 2. Operations & 1 & 2 & 7 & 4 & 5 & 19 & & & \\
\hline Workpla & Manager & $0,8 \%$ & $1,7 \%$ & $5,8 \%$ & $3,3 \%$ & $4,2 \%$ & $15,8 \%$ & 120 & $x^{2}=10,840$ & $\mathrm{p}=0,543$ \\
\hline ce & 3. Mid-level & 0 & 2 & 3 & 1 & 5 & 11 & $100 \%$ & $\mathrm{C}=0,288$ & $p>0,05$ \\
\hline & manager & $0,0 \%$ & $1,7 \%$ & $2,5 \%$ & $0,8 \%$ & $4,2 \%$ & $9,2 \%$ & & & \\
\hline & 4. Top & 0 & $\mathbf{0}$ & 2 & 3 & 2 & 7 & & & \\
\hline & Management & $0,0 \%$ & $0,0 \%$ & $1,7 \%$ & $2,5 \%$ & $1,7 \%$ & $5,8 \%$ & & & \\
\hline
\end{tabular}

\section{Source: Author}

As in the previous case and by analyzing the data in Table 6, we see that all independent variables are not significantly related to respondent attitudes about the possibility of implementing the reform of compulsory pension insurance. The value of the Chi-square test 
and the contingency coefficient $\mathrm{C}$ show that gender $(\mathrm{x} 2=5.761, \mathrm{C}=0.214$ and $\mathrm{p}=0.218)$, age $(\mathrm{x} 2=10.652, \mathrm{C}=0.286$ and $\mathrm{p}=0.222)$, profession $(\mathrm{x} 2=17.575, \mathrm{C}=0.357$ and $\mathrm{p}=0.129)$, work experience $(\mathrm{x} 2=11.318, \mathrm{C}=0.294$ and $\mathrm{p}=0.502)$ and the position of the respondents in the company $(\mathrm{x} 2=10.840, \mathrm{C}=0.288$ and $\mathrm{p}=0.543)$ are not statistically significantly related to the stated attitude of the respondents. This means that we have no significant deviations in respect of the said position. Based on the data from the table, we can conclude that regardless of gender, age, professional qualifications, working experience and position in the company, most respondents agree with the view that a mandatory pension insurance reform is necessary.

\section{CONCLUSION}

Pension insurance is the subject of debate and analysis in almost all countries of the world because a stable pension system is one of the prerequisites for economic growth and development. It is therefore important that there is pension security, regardless of whether the system can generate revenues sufficient to provide a socially acceptable living standard and their proper funding.

The problem of population aging and a decline in the birth rate leads to an unfavorable relationship between the number of employees and the number of pensioners. Adding to this is the economic crisis that has caused problems in the functioning of national economies in the last decade, all this contributing to the increase of contributions and problems with their collecting. This in turn leads to irregular payments of pensions, as well as an increasing deterioration of pensioners due to the small amount of pensions that often fail to provide to cover their existential needs. It is precisely for these reasons that a reform of the pension insurance system is in progress in many countries of the world. The existing public pension insurance system (1st pillar) becomes financially unsustainable, which necessitates the introduction of an additional one (2nd pillar) and voluntary pension insurance (3rd pillar).

It can be concluded that the main reasons for the reform of the compulsory pension insurance system is Serbia are the same as in the rest of the world: the efforts to reduce public spending and budget deficit, address the aging of the population, prevent early retirement and the need for greater coverage of the insured.The average pension in Serbia is among the lowest in Europe and cannot guarantee material security in old age.

Reforms should not be expected to solve all the problems of the pension system. The World Bank is no longer so categorical in applying the pension reform model which it previously advocated. It can therefore be said that it has conducted one type of experiment to examine how this model will look like in the practice of transition countries. In order to solve the problem of pension system deficits in the long run and improve the position of key retirees, the problem of unemployment needs to be resolved and production increased. This represents a harder path to healing, so to speak, but it is, of course, much more effective.

The globalization process has also affected the pension system as an important segment of the economy (public finances) as a whole, so that, along with unfavorable demographic trends, reforms are inevitable.

In this paper, in one place, the current situation and perspectives of pension systems are analyzed both in our country and in the world. It has been shown that many countries (especially countries in transition) have to transform their systems for financial, demographic and economic reasons.

By analyzing the data from the survey, we can conclude that the general hypothesis is confirmed: citizens are not satisfied with the existing situation in the pension insurance system, they 
consider the pension fund to be empty and that it fails to guarantee safe pensions. This means that the reforms implemented so far have not been sufficient and that they need to be continued.

There are significant differences between the populations of men and women regarding this issue: the pension fund is full and guarantees safe pensions. There are significant differences between age and age populations regarding this issue: mandatory pension insurance is excellent.

With other issues, there is no significant difference in opinion regardless of gender, age, professional qualifications, work experience and the position of the respondents in the company.

\section{REFERENCES}

[1] Anja, S., Ejmer, B. (2005), “O globalizaciji,” Columbia University Press, prevod: Ekonomist magazine.

[2] Ilić, A. (2016), "Reforma penzijskog sistema," Srpski ekonomski forum, Beograd.

[3] Jovanović, I. (2013), "Iskustva izvršenih reformi penzijskih sistema u zemljama Centralne i Istočne Evrope, ” Bilten Instituta G-17, broj 40-41, Beograd.

[4] Piljan, T., Piljan, I., Cogoljević, D., (2019), „Analiza poslovanja dobrovoljnih penzionih fondova u Republici Srbiji“, VOJNO DELO, ISSN 0042-8426; broj. 1, str. 194-210, Beograd.

[5] Matković G., Bajec J., Živković B., Stanić K., Mijatović B. (2018), "Izazovi uvođenja obaveznog privatnog penzijskog sistema u Srbiji," USAID i CLDS, Beograd.

[6] Ministarstvo finansija (2008), "Memorandum o budžetu i ekonomskoj politici za 2007.godinu sa projekcjama za 2008 i 2009 godinu, ” Beograd.

[7] Pak, J. (2017), "Promene u pravu osiguranja Srbije u okviru evropskog razvoja prava osiguranja, ” Zbornik radova Udruženje za pravo osiguranja Srbije, Beograd.

[8] Piljan I., Cogoljević D., Piljan, T., (2018), „Insurance as a factor for the development of the agricultural sector in the Republic of Serbia“, INTERNATIONAL SCIENTIFIC JOURNAL, „INERNATIONAL REVIEW“, ISSN 2217-9739, br. 1-2, str. 131-138, Beograd.

[9] Rakonjac-Antić, T. (2014), "Dobrovoljno penzijsko osiguranje," (Aktuarska i finansijska analiza), Centar za izdavačku delatnost, Ekonomski fakultet, Beograd.

[10] Rakonjac-Antić, T. (2018), "Penzijsko i zdravstveno osiguranje, ” Centar za izdavačku delatnost, Ekonomski fakultet, Beograd.

[11] Stojilković, J. (2018), “Baby boom generacije na pragu penzionisanja, ” Stanovništvo, 48, Beograd.

[12]Zakon o dobrovojnim penzijskim fondovima i penzijskim planovima, Sl. glasnik RS, br. $85 / 2005$ i 31/2011.

[13]Zakon o osiguranju iz 2004.godine, Službeni glasnik RS br. 55/04 i 70/04, Beograd.

[14] Wilets, D. (2017), "Old Europe? Demographic change and pension reform," (15.06.2017, www.cer.org).

[15] Mukesh, Betcherman \& Banerji (2017), "From red to white” (19.06.2017), www.sitersources.worldbank.org.

[16] http://zivotnoosiguranjeonline.com (01.06.2017).

\section{Article history:}

- Received 4 April 2019

- Accepted 12 May 2019 